\title{
Public Health Implication of Drinking Water Sources Contaminated with Giardia and Cryptosporidium in South Ethiopia
}

Mengistu Damitie ( $\sim$ mdamtie195@gmail.com )

Arba Minch University

Dante Santiago

Jimma University College of Public Health and Medical Sciences

Luc Leyns

Vrije Universiteit Brussel

Seid Tiku Mereta

Jimma University College of Public Health and Medical Sciences

Zeleke Mekonnen

Jimma University College of Public Health and Medical Sciences

\section{Research}

Keywords: Cryptosporidium, Giardia, Health risk, Water sources, Ethiopia

Posted Date: June 9th, 2020

DOI: https://doi.org/10.21203/rs.3.rs-31975/v1

License: (c) (i) This work is licensed under a Creative Commons Attribution 4.0 International License. Read Full License 


\section{Abstract}

Background: The concept of health is largely tied up with the quality of the ambient environment of human. There is a need to minimize the risks of environment to public health and comply with microbial contamination legislation stipulated by respective regulatory bodies. Though water borne protozoa are leading causes of diseases in socio-economically disadvantaged areas, less information is available about drinking water quality and its implication to the public. The present study aimed at characterizing the risks of Giardia and Cryptosporidium from water sources in southern Ethiopia.

Methods: Twenty-one drinking water samples (10L per source) were collected from five different types of water sources. Sample analysis was performed using immunofluorescence assay (IFA) with fluorescein isothiocyanate-monoclonal antibodies and nested PCR with tpi, SSU-rRNA and gp60 loci of the parasites. Statistical analysis was performed using Spearman's rho correlation and independent-samples nonparametric test.The risk was characterized using quantitative microbial risk assessment.

Results: The IFA and genotyping assays overall showed that Giardia was detected in $81 \%(17 / 21)$ of the samples with a mean concentration of 64.6 cysts. $10 \mathrm{~L}^{-1}$ and Cryptosporidium in $71 \%$ (15/21) with a mean concentration of 62.8 oocysts. $10 \mathrm{~L}^{-1}$. Out of the 17 Giardia positive water sources, Giardia duodenalis (assemblage B) was detected in $29.4 \%$, assemblage $A$ in $17.6 \%$ and assemblages $A+B$ in $52.9 \%$ of the sources. Likewise, Cryptosporidium genotype was detected in $57.1 \%(12 / 21)$ of the sources; C. parvum in $38.1 \%(8 / 21)$ and C. hominis in $14.3 \%(3 / 21)$ of the sources. The average probability of illness from the water sources was 0.06 for Giardia and 0.22 for Cryptosporidium.

Conclusions: The present finding highlights the significance of water for transmission of Giardia and Cryptosporidium in southern Ethiopia. Genotypes detected in the water sources indicate that multiple sources likely contaminated the drinking water sources. The health risks that are inferred from the water sources to the public are significantly higher than most other reported findings. This study recommends the need of regular follow-up, improvement in water treatment facilities and setting appropriate legislation in areas where cycles of parasitic infection is linked to water sources.

\section{Background}

As problems related to water pollution has become a global issue, there is a need to understand the risks of environment to public health and comply with microbial contamination legislations and guidelines stipulated by national or international regulatory bodies. Diarrheal diseases cause about $10 \%$ death of children $<5$ years; the majority occurs in sub-Saharan Africa and South Asia [1, 2]. Giardia and Cryptosporidium are among the leading causes of diarrhea diseases in children under five years [3], mainly in the tropics and socio-economically disadvantaged areas $[4,5,6]$. These parasites infect a wide range of hosts and are the most common parasitic infection of humans $[7,8,9,10,11]$. Giardia duodenalis ( $G$. duodenalis) infects about $5-10 \%$ of the world's population [12] and 200 million people per vear worldwide [13. 14l. More than one billion people are at risk of infection from G. duodenalis [9], Loading [MathJax]/jax/output/CommonHTML/fonts/TeX/fontdata.js 
though the frequency is high in developing countries and some deprived communities in developed countries $[4,5,14,15,16]$. Cryptosporidium species, predominantly Cryptosporidium parvum (C. parvum) and Cryptosporidium hominis (C. hominis) are known to infect humans $[8,10]$. The parasite causes serious health impact in immunocompetent individuals, resulting prolonged courses, relapses and extra intestinal sequelae in up to $40 \%$ of the cases $[17,18]$. About 2.9 million Cryptosporidium-attributable cases occur annually in children in sub-Saharan Africa $[3,19]$, imposing higher health impact in developing countries than in developed ones [20,21].

Giardia cysts and Cryptosporidium oocysts are ubiquitous in a variety of water sources and moist environmental settings $[6,22,23,24,25]$. Likewise, more than 300 million people in sub-Saharan Africa have poor access to safe water, which predisposes the peoples to infections from waterborne pathogens $[26$,27]. Poverty, as a key limiting factor to access safe water coupled to inadequate water treatment, poor hygiene practices, un-boiled water consumption and lack of education predisposes many rural African populations to giardiasis and cryptosporidiosis $[6,16]$. Perceiving the significant burdens of giardiasis and cryptosporidiosis with poverty in developing countries, the parasites have been included in the Neglected Diseases Initiative of World Health Organization [13].

These parasites remain as a serious public health defiance in the at-risk population, worsening socioeconomic conditions of peoples $[16,28,29]$. Studies that have been done in Ethiopia provided important epidemiological information, however risks and diseases burdens of the genotypes associated to water sources were not characterized. To minimize the risks and diminish the overall impacts of contaminants in water sources, availability of sufficient information on water quality and level of microbial contamination remains a problem in developing countries [16]. The present study aimed at assessing and characterizing risks of Giardia and Cryptosporidium spp. infection associated to water sources in southern Ethiopia.

\section{Materials And Methods}

\section{Study area and design}

This study was done from February to May 2016 in southern Ethiopia that consists of 13 administrative zones, covering about $10 \%$ of the landmass of Ethiopia. It is located in $4^{\circ} 43^{\prime}-8^{\circ} 58^{\prime} \mathrm{N}$ latitude and $34^{\circ} 88^{\prime}-39^{\circ} 14^{\prime} \mathrm{E}$ longitude with an altitude range of 376-4207 $\mathrm{m}$ above sea level. The annual rainfall and temperature range of $500-2200 \mathrm{~mm}$ and $15-30^{\circ} \mathrm{C}$, respectively. Drinking water sources in the region range from treated to untreated sources. The study area was selected using multi-stage cluster sampling technique; seven zones from the region and three districts from each zone were selected. Health risks were characterized using 21 different water sources that were selected from each district and 576 individuals that were using the water sources. Participants were selected based on a single proportion formula, considering design effect 1.5. According to the sample sizes allocated to each site, households were selected using systematic sampling technique, with an individual per household randomly selected. 
individuals that were not using the water sources were excluded. The water samples were analyzed quantitatively (IFA) and qualitatively (nested-PCR), and risks were characterized using quantitative microbial risk assessment (QMRA).

\section{Water Sample Collection}

Ten-liter water samples were collected from each source from points representing the nature of water sources. Samples were collected using a clean and sterilized plastic bottle that were washed three times with hot and distilled water, and analyzed according to U.S.EPA method 1623. Prior to sample collection, the sample bottles were partially filled, rinsed three times with the same water and drained from the sampler. Sand and other debris were avoided by carefully collecting water rinsing in to the water in lowturbidity and the bottles were filled to collect ten-liter water sample. Piped water samples were collected from reservoirs while stream/river water samples were collected at the edges that had low-flow turbidity and debris. The samples were immediately placed in a lightproof insulated box containing ice-packs with water to ensure rapid cooling and preserve the state of the water and shipped to the laboratory, Arba Minch University and overnight stored in a refrigerator at $4^{\circ} \mathrm{C}$ until processed. Water turbidity and free chlorine were measured immediately on the time of sample arrival, within $24 \mathrm{~h}$ of sample collection. Water turbidity was measured using a Hach 2100N turbidimeter (Hach, Loveland, CO, USA) and expressed in nephelometric turbidity units (NTU). Free chlorine in municipal water was measured using DPD chlorine test kit (La- Motte, Chestertown, MD, USA) and expressed in milligram per liter.

\section{Water Sample Processing}

Sample filtration, elution, concentration, application on slide and drying were carried out within 24 hours of collection. The samples were filtered through 142-mm-diameter with $3.0 \mu \mathrm{m}$-pore-size cellulose nitrate (Sartorius) membrane. The water sample was drawn through the membrane under negative pressure and the membrane was scraped with a smooth-edged plasticine molder and rinsed with $0.1 \%$ Tween 80 (T80). The membrane was rinsed repeatedly by turning it for three times until it became clean and the eluate was collected in a clean and sterilized plastic dish and transferred to a sterile $50 \mathrm{ml}$ centrifuge tube. The dish was rinsed with $0.1 \%$ T80, pooled with the resuspended pellet, centrifuged at $5000 \mathrm{~g}$ for $10 \mathrm{~min}$. All supernatant of a sample was aspirated to leave the pellet. The pellet was resuspended with $0.1 \%$ T 80 and transferred into a fresh sterile centrifuge tube. The emptied tube was rinsed with $0.1 \% \mathrm{~T} 80$, the washes were pooled with the resuspended pellet, centrifuged at $5000 \mathrm{~g}$ for $10 \mathrm{~min}$ and the supernatant was decanted. Pellets of the same sample were collected together and $0.5 \mathrm{ml}$ of each aliquot was used for detection and enumeration. The remaining portions were stored at $-20^{\circ} \mathrm{C}$ for genotypic analysis.

\section{Pathogen Detection And Enumeration}


Giardia cysts and Cryptosporidium oocysts were enumerated using immunofluorescence assay (IFA) and haemocytometer chamber. The IFA was done by transferring $10-\mu$ l aliquot of each sample, in triplicate. According to U.S.EPA $1623,10 \mu \mathrm{l}$ aliquot of each sample was directly transferred into separate slides, airdried at $55^{\circ} \mathrm{C}$ and placed in a dark humid chamber, and incubated at room temperature for 30 min with combined fluorescein isothiocyanate-monoclonal antibodies (FITC-Mab) (Aqua-Glo G/C kit; Waterborne, Inc., New Orleans, LA). The slides were removed from the chamber, the condensation was let evaporated, and one drop of wash buffer was applied to each well according to the manufacturer's instructions. The slides were washed in PBS containing T80 (0.01\% [vol/vol]; PBST), air-dried at $55^{\circ} \mathrm{C}$ and tilted on a clean paper towel, and the excess detection reagent was aspirated using a clean Pasteur pipette. The haemocytometer count was also performed by applying $1 \mu \mathrm{l}$ of the final pellet; five counts were performed per test.

The wells were counterstained each with $50 \mu \mathrm{l}$ of 4', 6-diamidino-2-phenylindole (DAPI) staining solution (Sigma, St. Louis, MO) at $0.4 \mu \mathrm{g} / \mathrm{ml}$ and stood at room temperature for $2 \mathrm{~min}$. A drop of the wash buffer was re-applied to each well, and the slides were tilted and processed as mentioned above. Mounting medium was added to each well and covered using cover slip. Excess mounting fluid was removed from edges of the coverslip using soft tissue and the edges were sealed onto the slides using clear nail polish and examined using epifluorescence. The primary FITC-Mab staining examination was conducted at minimum of 200X magnification with excitation/band-pass filters for FA-Filter set to examine FITC. The DAPI examination was conducted at minimum of 400X magnification with excitation/band-pass filters for DAPI-Filter set to examine DAPI. The DIC examination was conducted by increasing the magnification to 1000X. Shape, size and internal morphological features for each apple-green fluorescing object that met the size and shape characteristics of cysts and oocysts per pellet were enumerated. The total estimated numbers were calculated based on the analyzed fraction of pellet and total volume of filtered water.

Giardia and Cryptosporidium genotyping

\section{Dna Extraction}

The portions of each pellet was suspended by vortexing and $300 \mu \mathrm{l}$ of the sample was transferred directly into a $1.5 \mathrm{ml}$ centrifuge tube and centrifuged for 2 minutes at 13,000 rpm and the supernatant was discarded. The sediment was re-suspended in $300 \mu \mathrm{l}$ sterile distilled water and centrifuged at the same conditions three times repeatedly. The extraction was carried out using five freeze-thaw $\left(-70^{\circ} \mathrm{C}\right)$ cycles followed by QIAamp DNA Mini isolate kit (Qiagen, Germany) in accordance with the original protocol. The samples were washed seven times with $1 \mathrm{~mL}$ of PBS $(\mathrm{pH}=7.3)$ and centrifuged at $14000 \mathrm{~g}$ for $1 \mathrm{~min}$. The pellets collected in the preceding steps were re-suspended in $1400 \mu \mathrm{l}$ of buffer ASL, heated to $95^{\circ} \mathrm{C}$ for $10 \mathrm{~min}$, then vortexed, and centrifuged at $15000 \mathrm{~g}$ for $1 \mathrm{~min}$. The digestion process with proteinase $\mathrm{K}$ was elongated to $30 \mathrm{~min}$ at $70^{\circ} \mathrm{C}$. 
The genotypes were determined using the tpi gene based nested PCR, as it is a good phylogenetic marker for molecular analysis [30]. According to a previous work [31], primary and secondary primers that amplify 618 and 557 bp of the gene were used, respectively. In the primary PCR amplification, the external forward primer - TPI-FW1 (5'-CAGAAAATAAATIATGCCTGCTC-3') and external reverse primer TPI-RV1 (5'-CAAACCTTITCCGCAAACC-3') were used. The primary PCR amplification was carried out in $50 \mu \mathrm{l}$ reaction mixture containing $5 \mu$ l of DreamTaq ${ }^{\text {TM }}$ Buffer (10x), $1 \mu$ of dNTPs mix (10 $\mu \mathrm{M}$ each), $1 \mu \mathrm{l}$ of GlTPI-FW1 and $1 \mu$ l of GI-TPI-RV1 (10 $\mu \mathrm{M}$ each), $0.25 \mu$ of ( 5 Unit) Dream Taq DNA polymerase, $0.25 \mu \mathrm{g} / \mu \mathrm{l}$ of genomic DNA and nuclease free water. The reaction was carried out in 30 cycles, each consisting of $95^{\circ} \mathrm{C}$ for 45 seconds, $55^{\circ} \mathrm{C}$ for 45 seconds and $72^{\circ} \mathrm{C}$ for 1 minute with an initial hot start at $95^{\circ} \mathrm{C}$ for 5 minutes and a final extension for 7 minutes. In the secondary PCR amplification, the internal forward primer - TPI-FW2 (5'-CCCTTCATCGGIGGTAACTTCAA-3') and internal reverse primer TPI-RV2 (5'ACATGGACITCCTCTGCCTGCTC-3') were used. The reaction was carried out parallel to the primary PCR reaction, except using $4 \mu$ of the primary PCR product and prolonging the final extension to 10 minutes. The genotype of Giardia was detected and genotyped using $1.5 \%$ gel electrophoresis analysis of the final PCR amplicons. In every activity, both positive control (G. duodenalis DNA) and negative control (nuclease free water) were used.

\section{Cryptosporidium genotyping}

The SSU-rRNA gene of $C$. parvum and gp60 gene of $C$. hominis were amplified using nested PCR protocol. In the primary PCR of SSU-rRNA gene, external primers - CR-SSU-FW1 (5'-TTCTAGAGCTAATACATGCG$3^{\prime}$ ) and CR-SSU-RV1 (5'-CCCATTTCCTTCGAAACAGGA-3') that amplify 1,323 bp fragment of the gene were used. In the secondary PCR, internal primers -CR-SSU-FW2 (5'-

GGAAGGGTTGTATTTATTAGATAAAG-3') and CR-SSU-RV2 (5'-CTCATAAGGTGCTGAAGGAGTA-3') that amplify $852 \mathrm{bp}$ fragment of the gene were used. The primary PCR amplification of SSU-rRNA gene was carried out in $50 \mu \mathrm{l}$ reaction mixture containing $5 \mu \mathrm{l}$ 10X Dream Taq buffer, $1 \mu \mathrm{ldNTPs}$ mix (10 $\mu \mathrm{M}$ each), $1 \mu \mathrm{l} \mathrm{CR-SSU-FW1}$ and $1 \mu \mathrm{l} \mathrm{CR-SSU-RV1}$ (10 $\mu \mathrm{M}$ each), $0.25 \mu \mathrm{l}$ 5.00U Dream Taq DNA polymerase, $0.25 \mu \mathrm{g} / \mu \mathrm{l}$ of genomic DNA and nuclease free water. In the primary PCR reaction, 30 cycles were carried out, each consisting of $94^{\circ} \mathrm{C}$ for $45 \mathrm{~s}, 55^{\circ} \mathrm{C}$ for $45 \mathrm{~s}$ and $72{ }^{\circ} \mathrm{C}$ for 1 min., with an initial hot start at $94{ }^{\circ} \mathrm{C}$ for $3 \mathrm{~min}$ and a final extension for $7 \mathrm{~min}$. In the secondary PCR reaction, $4 \mu \mathrm{l}$ of the primary PCR product will be used and the cycles will be increased to 35 ; whereas, the other PCR conditions were parallel to the primary reaction.

In the primary PCR amplification of gp60 gene, external primers - CR-GP60-FW1 (5'TTACTCTCCGTTATAGTCTCC-3') and CR-GP60-RV1 (5'-GGAAGGAACGATGTATCTGA-3') that amplify $915 \mathrm{bp}$ fragment of the gene were used. In the secondary PCR, internal primers -CR-GP60-FW2 (5'TCCGCTGTATTCTCAGCC-3') and CR-GP60-RV2 (5'-GCAGAGGAACCAGCATC-3') that amplify 869 bp of the gene fragment were used. Except a different annealing temperature $\left(54^{\circ} \mathrm{C}\right)$, the PCR amplifications of C. hominis gp60 gene was analogous to $C$. parvum SSU-rRNA gene amplification. The genotypes were determined using $1.5 \%$ gel electrophoresis: $5 \mu$ l of the final PCR product with $2 \mu \mathrm{l} 6 \mathrm{X}$ loading dye at $110 \mathrm{~V}$ 
positive and negative controls. In addition, the primers were checked based on gene sequences available from GenBank, the primers were also pretested and the PCR conditions were optimized.

\section{Stock Suspension Preparation And Enumeration}

Human stool samples from patients infected with Giardia and Cryptosporidium were obtained from Arba Minch hospital, southern Ethiopia. The samples were suspended with distilled water and filtered through a $0.5-\mathrm{mm}$ sieve and concentrated by centrifugation at $1050 \mathrm{~g}$ for $10 \mathrm{~min}$ and the supernatant was decanted. Cysts and oocysts were isolated using percoll-sucrose gradient (specific gravity: 1.09-1.10) and centrifugation at $1050 \mathrm{~g}$ for $10 \mathrm{~min}$. Stock suspensions having concentrations of $10^{3}$ to $10^{4}$ cysts or oocysts per liter were prepared using reagent water (MilliQ, Millipore) with $0.01 \%$ Tween 20 . Enumeration was performed using haemocytometer chamber count (Bright-Line, Reichert, Buffalo, NY), to achieve the optimal counting accuracy, 10 different chambers were counted for each cyst/oocyst suspension.

Spiking suspensions having $10^{2}$ to $10^{3}$ concentrations of each cyst and oocyst per liter were prepared by dilution using a drop count procedure. Droplets (10-20 $\mu$ l) from the stock suspensions were pipetted onto the edge of a microscope slide and counted using bright light microscopy (bright field illumination, Nikon, Japan) at 250X and 400X magnifications for cysts and oocysts, respectively. The counts were replicated for three times and the concentrations of the organisms were established. In addition, the same volumes of the suspensions were directly transferred in to well slides, stained with FITC-MAb (Waterborne Inc., New Orleans) and enumerated using IFA.

\section{Recovery Efficiency And Detection Limit}

Initial recovery efficiency of the method was achieved by spiking known number of cysts/oocysts in to a $10 \mathrm{~L}$ reagent water and counting the recovered parasites in the spiked sample, in triplicate. Concentration of cysts/oocysts in each sample, the recovery efficiency and detection limit of the method were calculated using equations 1,2 and 3 , respectively.

Equation 1.(Oo) cystsconc. $=\frac{\text { Numberof }(\text { oo }) \text { cystsdetectedinsamplebyIFA }}{\text { Recoveryefficiencyforsamplebatch } \times \text { Samplevolume }}$

Equation 2.Rec. eff $(\%)=\frac{\text { Numberof }(\text { oo }) \text { cystsdetectedinthepositivecontrol }}{\text { Numberof }(\text { oo }) \text { cystsseededtopositivecontrol }} \times(100)$

Equation 3.Limitofdetection $=\frac{1}{\text { Recoveryefficiency } \times \text { Samplevolume }}$

The inter-assay recovery efficiency of the method was also assessed to reveal the variation in the different water samples. The effect of matrix on recovery efficiency of the method was determined using spiked environmental water samples that were collected from the same sources. To assure the absence of contamination throughout the analytical procedure, unspiked reagent water sample was analyzed

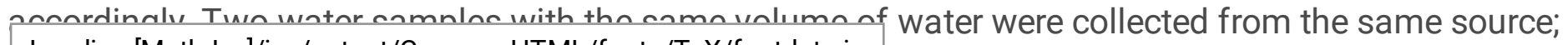
Loading [MathJax]/jax/output/CommonHTML/fonts/TeX/fontdata.js 
One sample for pathogen analysis and the other for recovery efficiency analysis. Spiking experiment per sample was carried out in triplicate and percent recovery (REC) was calculated according to [32], (Eq. 4). The number of cysts/oocysts in the water samples per $10 \mathrm{~L}$ were calculated, (Eq. 5).

Equation 4. $(R E C)=\frac{(N-N S A M P L E) / C C}{0.5 \mathrm{ml} / P V} \times(100)$

Where $N$ is the number of cysts/oocysts counted in the spiked water sample, NSAMPLE is number of cysts/oocysts counted in the unspiked environmental sample, $C C$ is the number of cysts/oocysts spiked and $P V$ is the analyzed pellet volume per sample.

Equation 5.(Oo) cysts $_{\mid \text {varvec } p \mid \text { varvece } \mid \text { varvecr10|varvec } L}=\frac{10}{V E} \times \frac{100}{R E C_{\text {avg }}} \times(N S A M P L E)$

Where $V E$ is volume examined, $R E C_{a v g}$ is average recovery of cysts/oocysts, and NSAMPLE is number of cysts/oocysts found in the unseeded water. When no cysts/oocysts were found, a value (detection limit) of each water type was used was used for NSAMPLE.

\section{Quantitative Microbial Risk Assessment}

Risks of the pathogens from drinking water sources were characterized using quantitative microbial risk assessment (QMRA). Exposure of individuals to Giardia and Cryptosporidium infections was determined based on concentration of cysts/oocysts in the water samples, as previously described [33, 34].

Individuals' exposure to each pathogen and the volume of water consumption through drinking exposure pathway per given amount of time, and water consumption behaviour of peoples (treatment practice before drinking) were gathered through a semi-structured questionnaire. Pathogen dose that are possibly ingested by an individual was computed as a product of volume of water consumed un-boiled or untreated in a given period and pathogen concentration in the water (Eq. 6). The daily dose of pathogen for treated water was computed according to [35], (Eq. 7). The probability of infection to each pathogen and its progress to illness were computed using an exponential dose-response model with parameters of an infection endpoint [36], (Eq. 8).

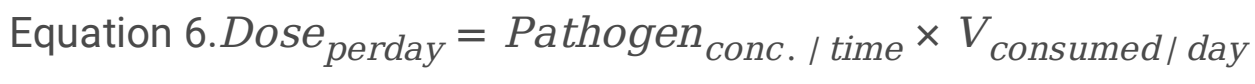

Equation 7.Dose $=C_{\text {perliter }} \times \frac{1}{R} \times I \times 10^{-D R} \times V$

Where $C$ is concentration of pathogens in the water or partially processed water, $R$ is recovery of the detection method, / is fraction of the detected pathogens that is capable of infection (viability), $D R$ is decimal reduction factor ( $D R=0$ when concentration in the finished water is available), and $V$ is daily individual consumption of the considered water.

Equation 8.P $P_{\text {Infection }}=1-\exp (-r D)$ 
Where $D$ is pathogen dose, and $r$ is fraction of pathogens that survives to produce an infection

An exponential dose-response model for representative species of Giardia and Cryptosporidium was considered to avoid response variations for exposure to a variety of species within a genus. Doseresponse model parameter, $r=0.0199$ for Giardia [37] and $r=0.09$ for Cryptosporidium [38, 39] were employed. Two parameters: $r=5.26 \times 10^{-3}$ for immunocompetent and $r=0.354$ for immunocompromised sub-populations were also accounted for $C$. parvum [40]. The probability of daily infection was extrapolated to yearly risk; consecutive exposures were assumed to be independent, then the probability of one or more infections for $n$ exposures per year was supposed to be the corollary of ' $n$. For daily infections with values of $<1$, infections per year were computed by multiplying the probability of daily infection and the number of days [36].

The probability of illness per given infection was computed using a morbidity fraction of each pathogen. Progression from infection to illness for Giardia and Cryptosporidium is ranged from 0.2 to 0.7 [36, 41, 42, 43]. A morbidity fraction of one was used to compute the probability of illness to Cryptosporidium infection for immunocompromised sub-populations [40]. The probability of morbidity was calculated according to [33,44], (equations 9). All the health outcomes of illness were considered as an endpoint and individuals were assumed to have at least one disease outcome.

Equation 9.P $P_{\text {Morbidity }}=P_{\text {Infection }} \times P_{\text {Ill } / \text { Inf }}$

Where, $P_{\text {Infection }}$ is the probability of infection with a specific pathogen, $P_{\text {ill/inf }}$ is the probability of illness due to infection.

\section{Questionnaire}

The study participants' information was collected using semi-structured questionnaire, which was pretested on a small number of respondents that were chosen randomly in the population being studied. The respondents were interviewed and their responses were documented and the questions were rephrased and interviews were repeated, then each response was investigated and comparable responses were maintained. Once the basis and procedures of the study were understood and agreed upon, the participants (parents of children) signed the informed consent forms and participated in the study. Then, the study subjects age, sex, type(s) of drinking water source(s), amount or volume water used for consumption per day, water consumption days per month and types of water treatment techniques or mechanisms used by individuals were collected (see Annex VA and VB).

\section{Statistical analysis}

Nonparametric Spearman's rho correlation coefficient was computed to assess how the occurrence rate of Giardia cysts and Cryptosporidium oocysts associated with the types of water sources and 
that are not distributed normally, moreover outliers have less of an effect on this statistical method. Correlation coefficients range in value from -1 (a perfect negative relationship), +1 (a perfect positive relationship) and a value of 0 (no linear relationship) were used to indicate the relationships of variables. In addition, independent-samples (Kruskal-Wallis) nonparametric test was performed to compare the distribution of cysts and oocysts across the types of water sources. In the analysis, $P<0.05$ were considered statistically significant. The analysis were performed with the IBM* SPSS* Statistics for Windows, version 23 software (SPSS Inc., Chicago, IL, USA).

\section{Results}

\section{Recovery efficiency and detection limit of the method}

Inter-assay recovery efficiency of the method showed variations in the types of water samples that were analyzed during the study. Percent recovery of the method was found in the range of 14 to $31 \%$ for cysts (mean: $22.4 \%$, SD: 5.248 ) and 13 to $25 \%$ for oocysts (mean: $19.7 \%$, SD: 3.985 ). The highest average percent recoveries of cysts and oocysts were achieved in river/stream and protected water samples and the lowest in unprotected spring water samples, respectively.

\section{Concentration of cysts/oocysts and correlation with water turbidity and free chlorine}

Giardia cysts and Cryptosporidium oocysts were detected in the drinking water sources in the region. The average concentrations of cysts and oocysts from different drinking water sources are indicated in Table 1. The highest average concentration of cysts and oocysts were detected in unprotected spring water samples and the lowest were found in river/stream and piped water samples. Independent-samples (Kruskal-Wallis) nonparametric tests showed distribution variation of cysts $(P=0.007)$ and oocysts $(P=$ $0.004)$ across the different categories of the water sources. However, Spearman's rho correlation coefficient showed no correlation between the types of water sources and occurrences of cysts $(P=$ $0.147)$ and oocysts $(P=0.129)$. Turbidity levels of the water samples ranged from $0.95-115$ NTU (mean: 35.8095, SD: 38.56852$)$; the highest value was observed in unprotected spring water samples and the lowest in piped water. The Spearman's rho correlation coefficient showed positive correlation between occurrence of cysts and water turbidity $(P=0.025)$, while there was no correlation between oocysts and water turbidity $(P=0.130)$. The concentration of free chlorine in piped water sample was found $\leq$ $0.55 \mathrm{mg} . \mathrm{L}^{-1}$ (mean: $0.1950, \mathrm{SD}: 0.20285$ ), though it was not statistically computed, as it was measured for piped water only. 
Table 1

The occurrence and concentration of cysts and oocysts in drinking water samples

\begin{tabular}{|c|c|c|c|c|c|c|c|c|c|}
\hline \multirow[t]{3}{*}{ Water samples } & \multirow[t]{3}{*}{ No. } & \multirow{2}{*}{\multicolumn{2}{|c|}{$\begin{array}{l}\text { Positive samples } \\
\text { (\%) }\end{array}$}} & \multicolumn{6}{|c|}{ Concentration $\left(10 . \mathrm{L}^{-1}\right)$} \\
\hline & & & & \multicolumn{2}{|l|}{ Mean } & \multicolumn{2}{|l|}{ Range } & \multicolumn{2}{|l|}{ SD } \\
\hline & & Cyst & Oocyst & Cyst & Oocyst & Cyst & Oocyst & Cyst & Oocyst \\
\hline Piped water & 6 & 50.0 & 33.3 & 7.3 & 2.6 & 20.0 & 10.5 & 8.9 & 4.4 \\
\hline $\begin{array}{l}\text { Protected } \\
\text { spring }\end{array}$ & 7 & 85.7 & 85.7 & 43.5 & 21.7 & 161.8 & 52.2 & 56.6 & 21.7 \\
\hline $\begin{array}{l}\text { Unprotected } \\
\text { spring }\end{array}$ & 5 & 100 & 100 & 198.7 & 229.4 & 399.9 & 460.3 & 176.9 & 191.9 \\
\hline River/stream & 3 & 66.7 & 33.4 & 4.9 & 1.5 & 11.1 & 4.5 & 5.6 & 2.6 \\
\hline Total & 21 & 76.2 & 71.4 & 64.6 & 62.8 & 476.3 & 493.6 & 115.8 & 129.2 \\
\hline
\end{tabular}

Genotypes of Giardia and Cryptosporidium

Giardia duodenalis, C. parvum and C. hominis genotypes were detected in the water samples. $G$. duodenalis was detected in $81 \%(17 / 21)$ of the samples similar to the IFA, except variation in one sample that was negative in IFA. Assemblage specific genotyping analysis of the isolates showed that genotypes in $29.4 \%(5 / 17)$ of the samples belonged to assemblage $B, 17.6 \%(3 / 17)$ belonged to assemblage $A$ and $52.9 \%(9 / 17)$ belonged to combination of both assemblages. All assemblage $B$ isolates, except one in piped water, were detected in unprotected spring water. Cryptosporidium genotypes were detected in $57.1 \%(12 / 21)$ of the samples and showed some variation with the IFA. C. parvum was identified in $38.1 \%$ $(8 / 21)$ of the samples, most of the parasites were detected in unprotected and protected spring water sources. C. hominis was detected in $14.3 \%(3 / 21)$ of the samples and all were in protected spring water. Combination of $C$. parvum and $C$. hominis was detected in one sample. Two samples, each from piped and protected spring water, that were positive for IFA were negative for $C$. parvum and $C$. hominis nestedPCR genotyping analysis. Coexisted C. parvum and G. duodenalis were also detected in some samples.

\section{Probability Of Infection And Risk Of Illness}

According to the information gathered through semi-structured questionnaire, $98.8 \%$ of the people had un-boiled water consumption habit. The average volume of water consumption per person per day was one-liter and frequency of consumption per month was 17 days (207 days/year). The average dose of cysts in all the water sources per one-liter volume of water ranged from 0.49 to 19.87 cysts L $^{-1}$ with an average dose of 6.46 cysts $L^{-1}$. The average dose of oocysts in the water sources per one-liter volume of water ranged from 0.15 to 22.94 oocysts $L^{-1}$ with an average dose of 6.28 oocysts $L^{-1}$. The highest dose of cysts and oocysts was observed in unprotected spring water sources and the lowest in river/stream 
illness per infection was determined using a morbidity fraction (0.5) of each pathogen (Table 2). The probability of infection and risk of illness to Cryptosporidium according to immune status of subpopulations is shown in Table 3. All individuals were assumed to have at least one disease outcome.

Table 2

Average doses of pathogens and probability of infection per case and risk of illness per infection (water consumption per day per person was calculated to be $1 \mathrm{~L}$ )

\begin{tabular}{|c|c|c|c|c|c|c|}
\hline \multirow{2}{*}{$\begin{array}{l}\text { Water } \\
\text { sources }\end{array}$} & \multicolumn{3}{|c|}{ Giardia } & \multicolumn{3}{|c|}{ Cryptosporidium } \\
\hline & $\begin{array}{l}\text { Dose } \\
\text { of } \\
\text { cyst }\end{array}$ & $\begin{array}{l}\text { Probability of } \\
\text { infection } r= \\
0.0199\end{array}$ & $\begin{array}{l}\text { Probability } \\
\text { of illness }\end{array}$ & $\begin{array}{l}\text { Dose } \\
\text { of } \\
\text { oocyst }\end{array}$ & $\begin{array}{l}\text { Probability of } \\
\text { infection } r= \\
0.09\end{array}$ & $\begin{array}{l}\text { Probability } \\
\text { of illness }\end{array}$ \\
\hline Piped water & 0.73 & 0.0144 & 0.0072 & 0.26 & 0.0231 & 0.0115 \\
\hline $\begin{array}{l}\text { Protected } \\
\text { spring }\end{array}$ & 4.35 & 0.0829 & 0.0414 & 2.17 & 0.1774 & 0.0887 \\
\hline $\begin{array}{l}\text { Unprotected } \\
\text { spring }\end{array}$ & 19.87 & 0.3266 & 0.1633 & 22.94 & 0.8731 & 0.4365 \\
\hline River/stream & 0.49 & 0.0097 & 0.0048 & 0.15 & 0.0134 & 0.0067 \\
\hline $\begin{array}{l}\text { Total } \\
\text { average }\end{array}$ & 6.46 & 0.1206 & 0.0603 & 6.28 & 0.4317 & 0.2158 \\
\hline
\end{tabular}

Table 3

The probability of Cryptosporidium infection and its progress to illness according to immune status of sub-populations

\begin{tabular}{|c|c|c|c|c|}
\hline \multirow{2}{*}{$\begin{array}{l}\text { Water } \\
\text { sources }\end{array}$} & \multicolumn{2}{|c|}{ Probability of infection } & \multicolumn{2}{|c|}{ Probability of illness } \\
\hline & $\begin{array}{l}\text { Immuno-competent } \\
r=5.26 \times 10^{-3}\end{array}$ & $\begin{array}{l}\text { Immuno- } \\
\text { compromised } r= \\
0.354\end{array}$ & $\begin{array}{l}\text { Immuno- } \\
\text { competent } P_{\text {ill/inf }} \\
=0.5\end{array}$ & $\begin{array}{l}\text { Immuno- } \\
\text { compromised } \\
P_{\text {ill/inf }}=1.0\end{array}$ \\
\hline Piped water & $1.4 \times 10^{-3}$ & $8.8 \times 10^{-2}$ & $7.0 \times 10^{-4}$ & $8.8 \times 10^{-2}$ \\
\hline $\begin{array}{l}\text { Protected } \\
\text { spring }\end{array}$ & $1.1 \times 10^{-2}$ & $5.4 \times 10^{-1}$ & $5.6 \times 10^{-3}$ & $5.4 \times 10^{-1}$ \\
\hline $\begin{array}{l}\text { Unprotected } \\
\text { spring }\end{array}$ & $1.1 \times 10^{-1}$ & $9.9 \times 10^{-1}$ & $5.7 \times 10^{-2}$ & $9.9 \times 10^{-1}$ \\
\hline River/stream & $8.0 \times 10^{-4}$ & $5.1 \times 10^{-2}$ & $4.0 \times 10^{-4}$ & $5.2 \times 10^{-2}$ \\
\hline $\begin{array}{l}\text { Total } \\
\text { average }\end{array}$ & $3.2 \times 10^{-2}$ & $8.9 \times 10^{-1}$ & $1.6 \times 10^{-2}$ & $8.9 \times 10^{-1}$ \\
\hline
\end{tabular}

\section{Discussion}


Environmental health is an indicator of human health. The concept of health is extremely tied up with the quality of the physical and socio-economic environment in which humans often depend on.

Environmental data based on scientific evidence provides a scientific basis to understand the health challenges and to infer the health status of humans living in the area playing a pivotal role for improvement of the public health. Although transmission of intestinal parasites through various ways have been reported, number of water-borne outbreaks have highlighted the importance of water as a main vehicle of Giardia and Cryptosporidium transmission. Infection is mostly occurring by exposure to drinking water contaminated with these pathogens $[44,45,46]$; excitingly, these parasites have been detected in packaged drinking water in Ghana $[23,25]$.

This is the first study in southern Ethiopia that characterized the morbidity risks of giardiasis and cryptosporidiosis from drinking water sources using quantitative and qualitative approaches. The overall analysis of both IFA and genotyping techniques showed that $G$. duodenalis (assemblages A and B) was detected in $81 \%(17 / 21)$ of the water sources whereas Cryptosporidium (C. parvum and C. hominis) in $71.4 \%(15 / 21)$ of the water sources. Similar to present study, studies in northern Spain [47] and Sao Paulo, Brazil [48] found elevated concentration of Giardia cysts and Cryptosporidium oocysts in most of untreated and treated municipal drinking water samples from conventional and small-scale water treatment facilities. The present study found the highest concentration of cysts and oocysts in unprotected water sources while the lowest was found in river water samples. However, the highest concentration of both parasites was reported in river water samples [48]. Both parasites were also detected in tap and treated water storage tanks in Ethiopia [22], springs in Cameroon [49], natural and communal piped water in Uganda [6], well, spring, tap and river waters in Zimbabwe [50], tap water, drinking water treatment plants in Egypt [24]. The correlation between the occurrence of cysts and water turbidity is also consistent with studies done elsewhere [47, 51].

According to the present findings, the average percentage risk of an individual to be infected with Giardia and Cryptosporidium per day was $12.1 \%$ and $43.2 \%$, respectively. The average risk of $C$. parvum infection were $3.2 \%$ for immunocompetent and $89.2 \%$ for immunocompromised sub-populations. The risks of illness per infection ranged from 0.48 to $16.33 \%$ to Giardia and 0.67 to $43.65 \%$ to Cryptosporidium. Though the probability of infection was lower than the present finding, a study [48] similarly showed that the probability of Giardia infection was close to the rates of acute diarrheic disease, $\leq 3 \%$ for adults and 2-7\% for children in Brazil. The present finding also accord with other studies that reported high risks for Giardia and Cryptosporidium infections from drinking water sources. A survey in 33 cities of China reported high burden of cryptosporidiosis in drinking water sources treated with conventional process. The overall rate of diarrhea morbidity was 149 cases per $10^{5}$ populations; 2701 cases per $10^{5}$ immunocompromised and 148 cases per $10^{5}$ immunocompetent persons [52]. Higher health risk was reported for immune-deficient subpopulation than immunocompetent individuals $[52,53]$. This showed that the risk of infection is peculiarly high for immunocompromised individuals [28].

Similarly, a risk assessment carried out in rivers of China similarly showed high health risk of giardiasis Loading [MathJax]/jax/output/CommonHTML/fonts/TeX/fontdata.js 4], which is much lower than the findings of the 
present study that used drinking as the only pathway of exposure. Africa apparently has the highest health risk that is almost double of the world average [27]. As water is a main vehicle of Giardia and Cryptosporidium transmissions, water treatment failure poses a significant risk to public health, as the parasites are resistant to most water treatment facilities $[22,29,54]$. The water quality in most developing countries mainly relies on a single microbial indicator and traditional treatment is primarily depended on chlorination, which are not adequate for pathogens that are resistant to such treatment facilities. Poor living condition that coincides with low accessibility to safe drinking water may associate with the highest health risk in most areas of the continent $[3,44,46,53]$. Therefore, the high disease burden in Ethiopia might be due to instability of water treatment process and less watershed protection, inadequate supply of safe water and poor environmental sanitation.

However, the present study has limitation on the period of sample collection. Sample was collected over a course of four months that leads to temporal/seasonal variation in water quality, especially in surface water due to precipitation and runoff. This may have an impact on the overall health risk.

\section{Conclusions}

Giardia and Cryptosporidium are serious public health defiance in southern Ethiopia, being major contributors to drinking water sources contamination. This highlights the significance of water for transmission of these parasites in the region. G. duodenalis (assemblages A and B), C. parvum and $C$. hominis are the genotypes detected in the water sources. Zoonotic and anthroponotic genotypes that are detected in the water sources implies that multiple contaminat sources likely play a role for contamination of water sources in the region. The risks that are inferred from the water sources to the public are significantly higher than most other reported findings. Since high concentration of cysts and oocysts are detected in the water sources and large amount of peoples can be affected on a daily basis, there is a need to remedy and diminish the risks to public health. To enhance science-based decision and ensure sustainability of the environment and public health, careful planning and regular monitoring of water sources, application of adequate and appropriate water treatment facilities, and setting appropriate legislation and guideline is needed, basically in areas where cycles of parasitic infection is linked to water sources.

\section{Abbreviations}

DAPI: 4', 6-diamidino-2-phenylindole; DPD: N, N-diethyl-p-phenylenediamine; FITC-Mab: Fluorescein isothiocyanate-Monoclonal Antibodies; gp60: Glycoprotein 60; IFA: Immunofluorescence Assay; NTU: Nephelometric Turbidity Units; PCR: Polymerase Chain Reaction; QMRA: Quantitative Microbial Risk Assessment; REC: Percent Recovery; SSU-rRNA: Small Subunit Ribosomal RNA; T80: Tween 80; USEPA: United States Environmental Protection Agency.

\section{Declarations}




\section{Ethical Approval and Consent to participate}

The study protocol was reviewed and approved by Ethics Committee of Jimma University, Ethiopia.

\section{Consent for publication}

Not applicable.

\section{Availability of supporting data}

The data analyzed during this study are included in this manuscript.

\section{Competing interests}

The authors declare that they have no competing interests.

\section{Funding}

This research article has got no funds.

\section{Authors' contributions}

MD involved in all phases of the study; study design, data collection, laboratory works, analysis and writing the manuscript. ZM, STM, DS and LL supervised the study and revised the manuscript. All authors read and approved the final paper.

\section{Acknowledgements}

The authors are deeply acknowledged Jimma University, Ethiopia and VUB, Belgium for granting us permission to conduct this research. We also like to pass our gratitude and acknowledgement to $\mathrm{Mr}$. Kibiralem Sisay and to the late Mr. Girma Tefera, from the Department of Statistics at Jimma University, for their active assistance in the statistical data analysis of this study. Thank you also to all the individuals in southern Ethiopia who voluntarily participated in this study

\section{Authors' information}

${ }^{1}$ Department of Environmental Health Sciences and Technology, Jimma University, Jimma, Ethiopia 
${ }^{2}$ School of Public Health, College of Medicine and Health Sciences, Arba Minch University, Arba Minch, Ethiopia

${ }^{3}$ Department of Biology, Faculty of Science and Bioengineering Sciences, Vrije Universiteit Brussel, Brussels, Belgium

${ }^{4}$ School of Medical Laboratory Sciences, Jimma University, Jimma, Ethiopia

\section{References}

1. Liu A, Zhang X, Zhang L, Wang R, Li X, Shu J, et al. Occurrence of bovine giardiasis and endemic genetic characterization of Giardia duodenalis isolates in Heilongjiang Province, in the Northeast of China. Parasitol Res. 2012;111:655-61.

2. Walker CLF, Aryee MJ, Boschi-Pinto C, Black RE. Estimating diarrhea mortality among young children in low and middle-income countries. PLoS One. 2012;7(1):e29151.

3. Kotloff KL, Nataro JP, Blackwelder WC, Nasrin D, Farag TH, Panchalingam S, et al. Burden and aetiology of diarrhoeal disease in infants and young children in developing countries (the Global Enteric Multicenter Study, GEMS): a prospective, case-control study. Lancet. 2013;382:209-22. http://dx.doi.org/10.1016/S0140-6736(13)60844-2.

4. Muhsen K, Levine MM. A systematic review and meta-analysis of the association between Giardia lamblia and endemic pediatric diarrhea in developing countries. Clin Infect Dis. 2012;55:271-93.

5. Escobedo AA, Arencibia R, Vega RL, Rodriguez-Morales AJ, Almirall P, Alfonso AM. A bibliometric study of international scientific productivity in giardiasis covering the period 1971-2010. J Infect Dev Ctries. 2015;9(01):076-86. doi:https://doi.org/10.3855/jidc.5785.

6. Sente C, Erume J, Naigaga I, Mulindwa J, Ochwo S, Magambo PK, et al. Prevalence of pathogenic free-living Amoeba and other protozoa in natural and communal piped tap water from Queen Elizabeth protected area, Uganda. Infect Dis Poverty. 2016;5(1):68.

7. Ankarklev J, Jerlström-Hultqvist J, Ringqvist E, Troell K, Svärd SG. Behind the smile: cell biology and disease mechanisms of Giardia species. Nat Rev Microbiol. 2010;8(6):413-22.

8. Xiao L. Molecular epidemiology of cryptosporidiosis: an update. Exp Parasitol. 2010;124(1):80-9. http://dx.doi.org/10.1016/ j.exppara.2009.03.018.

9. Feng Y, Xiao L. Zoonotic potential and molecular epidemiology of Giardia species and giardiasis. Clin Microbiol Rev. 2011;24(1):110-40. doi:10.1128/CMR.00033-10.

10. Ryan UNA, Fayer R, Xiao L. Cryptosporidium species in humans and animals: current understanding and research needs. Parasitology. 2014;141(13):1667-85.

11. Platts-Mills JA, Babji S, Bodhidatta L, Gats J, Haque R, Havt A, et al. Pathogen-specific burdens of cummunity diarrhea in developing countries: A multisite birth cohort study (MAL-ED). Lancet Glob Health. 2015;3(9):e564. https://doi.org/10.1016/S2214-109X(15)00151-5. 
12. Baldursson S, Karanis P. Waterborne transmission of protozoan parasites: review of worldwide outbreaks-an update 2004-2010. Water Res. 2011;45:6603-14.

13. Savioli L, Smith H, Thompson A. Giardia and Cryptosporidium join the 'Neglected Diseases. Initiative' Trends Parasitol. 2006;22(5):203-8. https://doi.org/10.1016/j.pt.2006.02.015.

14. Yoder JS, Gargano JW, Wallace RM, Beach MJ. Centers for Disease Control and Prevention (CDC). Giardiasis Surveillance-United States, 2009-2010. MMWR Surveill Summ. 2012;61:13-23.

15. Barry MA, Weatherhead JE, Hotez PJ, Woc-Colburn L. Childhood parasitic infections endemic to the United States. Pediatr Clin North Am. 2013; 60: 471 - 85. 13.

16. WHO. World Health Statistics. Geneva, Switzerland. World Health Organization; 2015. http://apps.who.int/iris/bitstream/10665/170250/1/9789240694439_eng.pdf.

17. Soba BS, Petrovec M, Mioc V, Logar J. Molecular characterization of Cryptosporidium isolates from humans in Slovenia. Clin Microbiol Infect. 2006;12:918-21.

18. Jex AR, Smith HV, Nolan MJ, Campbell BE, Young ND, Cantacessi C, et al. Cryptic parasite revealed improved prospects for treatment and control of human cryptosporidiosis through advanced technologies. Adv Parasitol. 2011;77:141-73. doi:10.1016/B978-0-12-391429-3.00007-1.

19. Sow SO, Muhsen K, Nasrin D, Blackwelder WC, Wu Y, Farag TH, et al. The burden of Cryptosporidium diarrheal disease among children $<24$ months of age in moderate/high mortality regions of subSaharan Africa and South Asia, utilizing data from the Global Enteric Multicenter Study (GEMS). PLoS Negl Trop Dis. 2016;10(5):e0004729.

20. Molloy SF, Tanner CJ, Kirwan P, Asaolu SO, Smith HV, Nichols RAB, et al. Sporadic Cryptosporidium infection in Nigerian children: risk factors with species identification. Epidemiol Infect. 2011;139(6):946-54.

21. Ghenghesh KS, Ghanghish K, El-Mohammady H, et al. Cryptosporidium in countries of the Arab world: the past decade (2002-2011). Libyan J Med. 2012; 7: doi: 10.3402/ljm. v7i0.19852.

22. Atnafu T, Kassa H, Keil C, Fikrie N, Leta S, Keil I. Presence, viability and determinants of Cryptosporidium oocysts and Giardia cysts in the Addis Ababa water supply and distribution system. Water Qual Expo Health. 2012;4(1):55-65.

23. Osei AS, Newman MJ, Mingle JAA, Ayeh-Kumi PE, Kwasi MO. Microbiological quality of packaged water sold in Accra, Ghana. Food Control. 2013;31(1):172-5.

24. El-Kowrany SI, El-Zamarany EA, El-Nouby KA, El-Mehy DA, Ali EAA, Othman AA, et al. Water pollution in the Middle Nile Delta, Egypt: an environmental study. J Adv Res. 2016;7(5):781-94.

25. Ndur S, Kuma J, Buah W, Galley J. Quality of Sachet water produced at Tarkwa, Ghana. Ghana Min J. 2016;15(1):22-34.

26. Yongsi HBN. Suffering for water, suffering from water: access to drinking water and associated health risks in Cameroon. J Health Popul Nutr. 2010;28(5):424-35.

27. WHO. Methods and data sources for global burden of disease estimates 2000-2011. Geneva: Department of Health Statistics and Information Svstems. World Health Organization; Loading [MathJax]/jax/output/CommonHTML/fonts/TeX/fontdata.js 
2013.http://www.who.int/healthinfo/statistics/GlobalDALYmethods 2000 2011.pdf.

28. Budu-Amoako E, Greenwood SJ, Dixon BR, Barkema HW, McClure JT. Foodborne illness associated with Cryptosporidium and Giardia from livestock. J Food Prot. 2011;74(11):1944.

29. Harhay MO, Horton J, Olliaro PL, Utzinger J. Diagnostics are central for a truly holistic approach against intestinal parasitic diseases. Int $\mathrm{J}$ Infect Dis. 2011;15:e76-7.

30. Sulaiman IM, Fayer R, Bern C, Gilman RH, Trout JM, Schantz PM, et al. Triosephosphate isomerase gene characterization and potential zoonotic transmission of Giardia duodenalis. Emerg Infect Dis. 2003;9:1444-52.

31. 10.1371/journal.pone.0097708

Lobo ML, Augusto J, Antunes F, Ceita J, Xiao L, Codices V, et al. Cryptosporidium spp., Giardia duodenalis, Enterocytozoon bieneusi and other intestinal parasites in young children in Lobata Province, Democratic Republic of Sao Tome and Principe. PLoS ONE. 2014; 9(5): e97708. doi: 10.1371/journal.pone.0097708.

32. Francy DS, Simmons OD, Ware MW, Granger EJ, Sobsey MD, Schaefer FW. Effects of Seeding Procedures and Water Quality on Recovery of Cryptosporidium Oocysts from Stream Water by Using U.S. Environmental Protection Agency Method 1623. Appl Environ Microbiol. 2004;70(7):4118-28. doi:10.1128/AEM.70.7.4118-4128.2004.

33. Gehlhaus Martin W, Gift Jeffrey S, Hogan Karen A, Kopylev Leonid, Schlosser Paul M. Kadry AbdelRazak. Approaches to cancer assessment in EPA's Integrated Risk Information System. Toxicol Appl Pharmacol. 2011;254:170-80.

34. USEPA. Exposure factors handbook: 2011 edition. Washington, DC: National Center for.

35. Environmental Assessment. Office of Research and Development. United States Environmental Protection Agency; 2011.

36. Teunis PF, van der Heijden OG, van der Giessen JWB, Havelaar AH. The Dose-response relation in human volunteers for gastro-intestinal pathogens. The Netherlands: RIVM; 1996.

37. Haas CN, Rose JB, Gerba CP. Quantitative Microbial Risk Assessment, editors, J.W. Wiley, Inc; 1999.

38. Rose JB, Haas CN, Regli S. Risk assessment and control of waterborne giardiasis. Am J Pub Health. 1991;81(6):709-13.

39. USEPA. Method 1623: Cryptosporidium and Giardia in water by filtration/IMS/FA. In: EPA 815-R-05002. Washington, DC: Office of Research and Development, Government Printing Office. United States Environmental Protection Agency; 2005.

40. USEPA. Ultraviolet disinfection guidance manual for the final long term 2 enhanced surface water treatment rule. Washington, DC: United States Environmental Protection Agency; 2006.

41. Pouillot R, Beaudeau P, Denis JB, Derouin F. A quantitative risk assessment of waterborne cryptosporidiosis in France using second-order Monte Carlo simulation. Risk Anal. 2004;24(1):1-17.

42. Mintz ED, Hudson-Wragg M, Mshar P, Cartter ML, Hadler JL. Foodborne giardiasis in a corporate office settinq. J Infect Dis. 1993;167(1):250-3.

Loading [MathJax]/jax/output/CommonHTML/fonts/TeX/fontdata.js

Page 18/19 
43. DuPont HL, Chappell CL, Sterling CR, Okhuysen PC, Rose JB, Jakubowski W.

44. The infectivity of. Cryptosporidium parvum in healthy volunteers. N Engl J Med. 1995;332(13):8559.

45. Okhuysen PC, Chappell CL, Sterling CR, Jakubowski W, DuPont HL. Susceptibility and serologic response of healthy adults to reinfection with Cryptosporidium parvum. Infect Immun. 1998;66:4413.

46. An W, Zhang D, Xiao S, Yu J, Yang M. Risk assessment of Giardia in rivers of southern China based on continuous monitoring. J Environ Sci. 2012;24(2):309-13. doi:10.1016/S1001-0742(11)60768-7.

47. Chalmers RM. Waterborne outbreaks of cryptosporidiosis. Ann Dell Ist Super Di Sanita. 2012;48(4):429.e446.

48. Machdar E, van der Steen NP, Raschid-Sally L, Lens PNL. Application of Quantitative Microbial Risk Assessment to analyze the public health risk from poor drinking water quality in a low income area in Accra, Ghana. Sci Total Environ. 2013;449:134-42.

49. Carmena D, Aguinagalde X, Zigorraga C, Fernandez-Crespo JC, Ocio JA. Presence of Giardia cysts and Cryptosporidium oocysts in drinking water supplies in Northern Spain. J Appl Microbiol. 2007;102:619-29. doi:10.1111/j.1365-2672.2006.03193.x.

50. Sato MI, Galvani AT, Padula JA, Nardocci AC, Lauretto Mde S, Razzolini MT, et al. Assessing the infection risk of Giardia and Cryptosporidium in public drinking water delivered by surface water systems in Sao Paulo State, Brazil. Sci Total Environ. 2013;442:389-96. http://doi.

10.1016/j.scitotenv.2012.09.077.

51. Ajeagah GA. Occurrence of bacteria, protozoans and metazoans in waters from two semi-urbanized areas of Cameroon. Ecohydrol Hydrobiol. 2013;13(3):218-25.

52. Dalu T, Barson M, Nhiwatiwa T. Impact of intestinal microorganisms and protozoan parasites on drinking water quality in Harare, Zimbabwe. J Water Sanit Hyg Dev. 2011;1(3):153-63.

53. Swaffer BA, Vial HM, King BJ, Daly R, Frizenschaf J, Monis PT. Investigating source water Cryptosporidium concentration, species and infectivity rates during rainfall-runoff in a multi-use catchment. Water Res. 2014;67:310-20. http://dx.doi.org/10.1016/j.watres.2014.08.055.

54. Xiao S, An W, Chen Z, Zhang D, Yu J, Yang M. The burden of drinking water-associated cryptosporidiosis in China: the large contribution of the immunodeficient population identified by quantitative microbial risk assessment. Water Res. 2012b;46(13):4272-80. doi:10.1016/j.watres.2012.05.012.

55. Xiao S, An W, Chen Z, Zhang D, Yu J, Yang M. Occurrences and genotypes of Cryptosporidium oocysts in river network of southern-eastern China Parasitol Res. 2012a; 110(5): 1701-1709.

56. Hlavsa MC, Roberts VA, Anderson AR, Hill VR, Kahler AM, Orr M. CDC et al. Surveillance for waterborne disease outbreaks and other health events associated with recreational water-United States, 2007-2008. MMWR Surveill Summ. 2011; 60(SS-12). 